\title{
Climate-change and mass mortality events in overwintering monarch butterflies
}

\section{Eventos de mortandad masiva y cambio climático en poblaciones invernales de la mariposa monarca}

Narayani Barve, Alvin J. Bonilla, Julia Brandes, J. Christopher Brown, Nathaniel Brunsell, Ferdouz V. Cochran, Rebecca J. Crosthwait, Jodi Gentry, Laci M. Gerhart, Trish Jackson, Anna J. Kern, Karen S. Oberhauser, Hannah L. Owens, A. Townsend Peterson ${ }^{凶}$, Alexis S. Reed, Jorge Soberón, Adam D. Sundberg and Linda M. Williams

C-CHANGE IGERT Program, University of Kansas, Lawrence, Kansas 66045 USA.

\town@ku.edu

\begin{abstract}
Monarch butterflies (Danaus plexippus) have a unique yearly life cycle, in which successive generations breed and move northward from the southern USA in spring to the northern US and southern Canada by late summer; they overwinter in extremely restricted areas in central Mexico and along the California coast. Mexican overwintering populations have experienced significant mortality events recently, which have been hypothesized as increasing in frequency owing to climate change. Here, we test the hypothesis of climate-change causation of these mortality events, at least in part, finding significant local weather trends toward conditions lethal for monarch survival. We use ecological niche estimates and future climate projections to estimate future overwintering distributions; results anticipate dramatic reductions in suitability of present overwintering areas, and serious implications for local human economies.
\end{abstract}

Key words: monarch butterfly, mortality, lethal temperature, winter, climate change.

Resumen. La mariposa monarca (Danaus plexippus) tiene un ciclo de vida singular, en el cual generaciones sucesivas se reproducen y migran hacia el norte, empezando en el sur de los Estados Unidos en la primavera y terminando en el norte de los Estados Unidos y sur del Canadá en verano. Pasan el invierno en unas pocas zonas muy restringidas del centro de México y la costa del estado de California. En tiempos recientes, las poblaciones en México han experimentado mortalidades significativas y se ha hipotetizado que la causa puede ser el cambio climático. En este artículo probamos, al menos en parte, la hipótesis del cambio climático como causa de estos eventos de mortalidad y encontramos un desplazamiento significativo del clima local hacia condiciones que son letales para la mariposa. Utilizamos estimados de nicho ecológico y proyecciones de climas futuros para definir futuras áreas de invernación. Nuestros resultados anticipan una reducción dramática en la calidad de estas áreas actuales e implicaciones serias para las economías locales.

Palabras clave: mariposa monarca, mortandad, temperatura letal, invierno, cambio de clima.

\section{Introduction}

The yearly cycle of monarch butterflies (Danaus plexippus) is well known: successive generations begin a series of breeding events and movements from the southern USA in spring to the northern US and southern Canada by late summer (Malcolm and Zalucki, 1993). Each fall, with decreasing temperatures and day lengths, they migrate $\sim 5000 \mathrm{~km}$ to spend the winter at a few sites in central Mexico and along the California coast (Brower, 1995). Mexican overwintering populations have experienced significant mortality events recently, in which $75 \%\left(>10^{7}\right.$

Recibido: 08 agosto 2011; aceptado: 23 marzo 2012 individuals in one case) died in a few nights (Brower et al., 2004).

Monarchs gather in dense overwintering clusters with an ecological profile distinct from that of breeding populations (Batalden et al., 2007). This annual cycle likely offers advantages as regards areas where they can breed successfully without in situ overwintering mechanisms (e.g., freeze tolerance). However, inability to deal with year-round conditions at northern sites may make them vulnerable to changing conditions at current overwintering sites.

Recent decades have seen several overwintering monarch mortality events apparently related to local weather (Brower et al., 2004): cold and wet conditions, particularly at night, and particularly when wet conditions 
immediately precede cold conditions, move monarchs into lethal physiological regimes that cannot be survived for more than a few hours. Experimental studies have elucidated tolerances of such conditions (Calvert et al., 1983; Gibo and McCurdy, 1993; Larsen and Lee, 1994; Anderson and Brower, 1996; Troyer et al., 1996; AlonsoMejía et al., 1997). Although such events may have occurred in the past, one publication suggested that frequency will increase with current climate change (Oberhauser and Peterson, 2004), with possible consequences for survival of the concentrated overwintering phenomenon.

In this contribution, we provide a partial test of these hypotheses of climate-change causation of winter mortality events. We then use ecological niche estimates and future climate projections to estimate future overwintering distributions. The results are discussed not only in biological terms (i.e., what is the future of the overwintering monarch butterfly phenomenon?), but also in terms of manifold implications for the local human communities.

\section{Materials and methods}

We based our inferences on locations of monarch butterfly overwintering colonies listed in a recent summary (García-Serrano et al., 2004). Weather station data were derived from the Mexican Servicio Meteorológico Nacional, with data access mediated by the Comisión Nacional para el Conocimiento y Uso de la Biodiversidad. We identified all weather stations falling within $25 \mathrm{~km}$ of known overwintering colonies -9 in total - that have complete nightly data for the key winter period (December - February) for the years listed in Table 1. These weather stations were the focus of our analyses of trends in weather/ climate conditions.

We measured distance in a two-dimensional climate space (temperature and precipitation) to conditions identified as lethal for overwintering monarch butterflies in physiological studies (Anderson and Brower, 1996), illustrated in Figure 1. The weather data were in the form of hourly measurements of temperatures, so we focused on the minimum distance to lethal conditions measured at any time during each $24 \mathrm{hr}$ period (precipitation data were managed at the level of whole days) in December-February for each year. We counted the absolute minimum distance to lethal conditions over each winter season (which was frequently zero, and thus lacking statistical power), numbers of nights presenting lethal conditions over the winter season, and the average minimum daily distances to lethal conditions over the winter season. While ideal tracking of lethal conditions would focus on situations in which precipitation precedes cold temperatures, this detail was not available to us for these analyses. These yearly metrics were then regressed on year for the periods 19802005 and 1995-2005.

For assessment of future potential distributions of overwintering monarchs, our methods followed those of Batalden et al. (2007) closely, and for that reason will not be repeated here, except in summary. We drew occurrence data from published sources (García-Serrano et al., 2004), and related them to 7 'bioclimatic' layers drawn from the WorldClim climate data archive (Hijmans et al., 2005) using the evolutionary computing algorithm called GARP (Stockwell and Peters, 1999). The resulting model of the ecological niche of overwintering monarch populations was projected onto 2 scenarios of future climate: the HadCM3 2050 simulation of the A2 and B2 emissions scenarios, downscaled to 2.5 ' resolution using standard methods (Peterson et al., 2002). Areas matching the niche requirements of the species on these future climate scenarios were taken as potential distributional areas for the species. Data on forest cover and ANP distributions were obtained from the Comisión Nacional para el Uso y Conocimiento de la Biodiversidad, government of Mexico (http://www.conabio.gob.mx).

\section{Results}

Using data from 9 weather stations $\leq 25 \mathrm{~km}$ of current Mexican overwintering sites (Table 1), we tested the hypothesis that winter conditions have shifted towards conditions lethal to overwintering monarch butterflies in recent decades. We derived 3 measures of such shifts: minimum and average distance in climate space to lethal conditions, and the number of nights presenting lethal conditions, all during December-February. We tracked these trends over 1980-2005 and 1995-2005 as linear regression slopes relating proximity to lethal conditions to year. Consistently negative slopes would reject the null hypothesis of no relationship, pointing to the alternative hypothesis of long-term trends in lethality of on-ground conditions.

Two temperature-precipitation scenarios of lethal conditions for overwintering monarchs were explored (Calvert et al., 1983; Gibo and McCurdy, 1993; Larsen and Lee, 1994; Anderson and Brower, 1996; Troyer et al., 1996; Alonso-Mejía et al., 1997) (Fig. 1). Although different weather stations presented distinct trajectories of average distance to lethal conditions (Fig. 2), the 2 scenarios yielded similar results, almost always of the same sign (Table 1). Over the broader period (1980-2005), results were mixed, with no clear temporal trends; however, over the shorterterm period (1995-2005), patterns were clearer: the only significant trend (weather station 16122) in minimum 


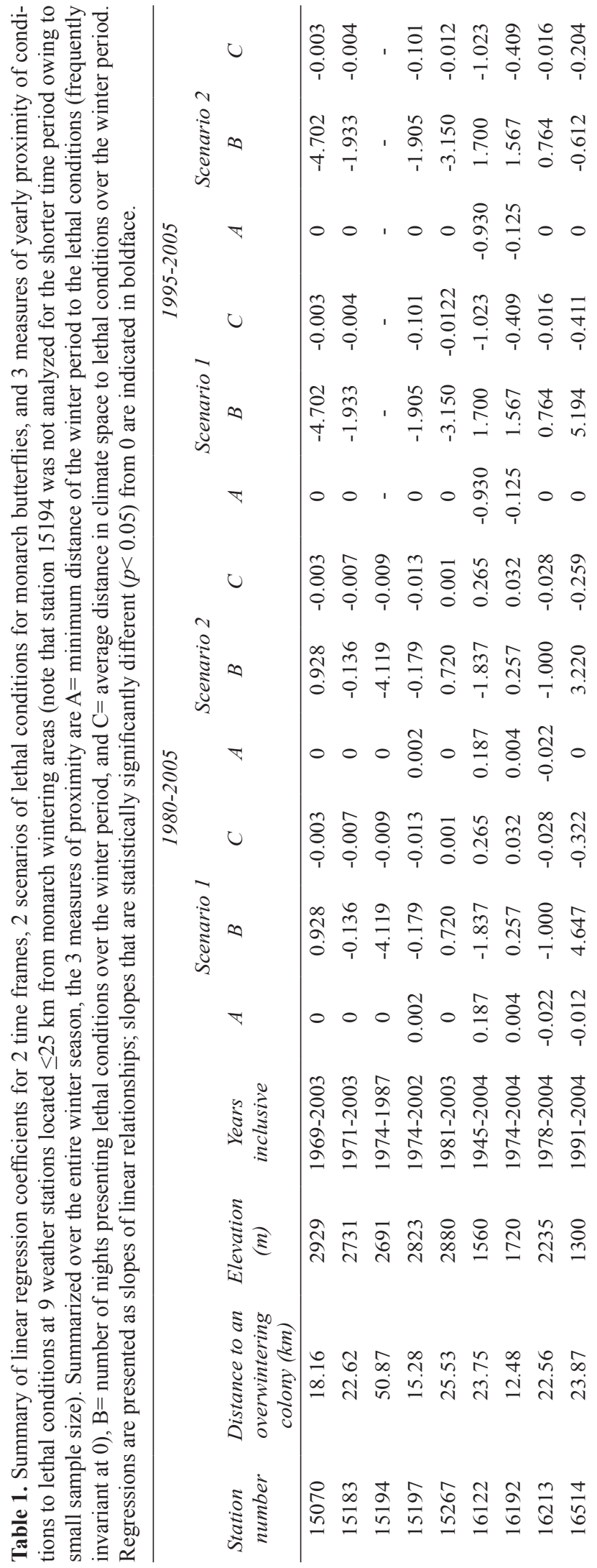

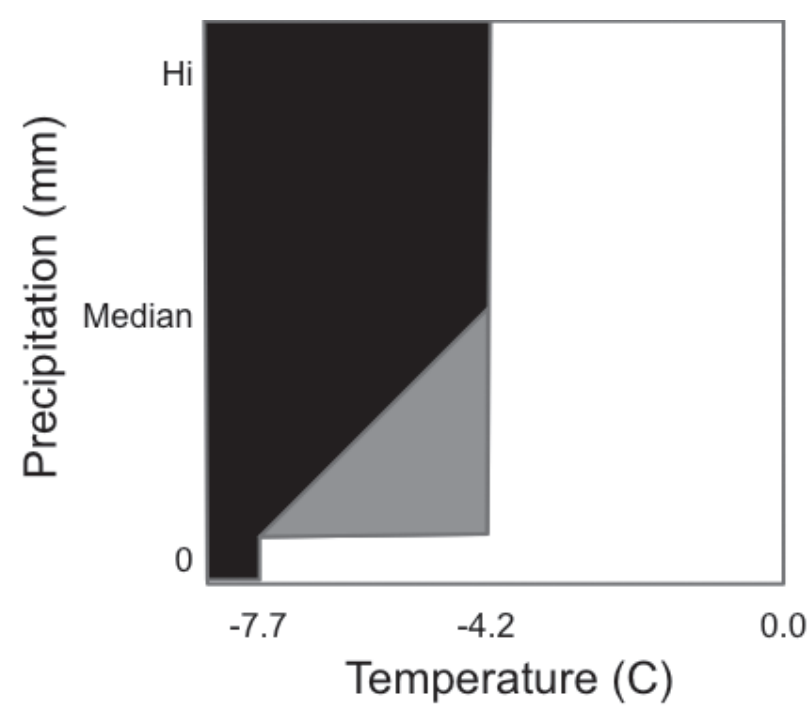

Figure 1. Illustration of 2 scenarios of lethal conditions of precipitation and temperature analyzed in this paper, based on different interpretations of the physiological results. Scenario A: High mortality at $-7.7^{\circ} \mathrm{C}$, low mortality at higher temperatures (i.e., black and gray areas are lethal); Scenario B: same as Scenario A, except that mortality is reduced gradually up to median temperature conditions for the site (i.e., black areas only are lethal).

distance to lethal conditions was statistically significantly negative. Although no regressions were significant for number of lethal nights over the shorter time period, 5 of 8 were negative in sign. Most markedly, trends in average distance to lethal conditions were overwhelmingly negative; indeed, all 8 weather stations with sufficient data showed negative trends, highly unlikely were they to be varying at random (sign test, $p<0.05$ ); 4 of these negative regression slopes were statistically significantly different from zero.

Using niche modeling methods (Peterson et al., 2011), future projections of areas presenting suitable conditions for overwintering monarchs (Figs. 3, 4) show that suitable conditions at present overwintering sites will likely reduce in extent by $73-100 \%$ over coming decades. Sites farther east - the Chichinautzín, La Malinche, Ixtaccihuatl, and Popocatépetl volcanoes (Fig. 3b) - are projected to retain more suitable conditions, but the only forested areas coinciding with suitable climate conditions are in the current MBBR. Indeed, suitable climate, protected area status, and forest show essentially no overlap by 2050 .

Monarchs present a particularly relevant case of climate-change effects on populations. Direct physiological measurements (Calvert et al., 1983; Gibo and McCurdy, 1993; Larsen and Lee, 1994; Anderson and Brower, 1996; Troyer et al., 1996; Alonso-Mejía et al., 1997) show that monarchs are sensitive to local microclimatic conditions, so climate change likely translates into factors relevant to overwinter survival (Oberhauser and Peterson, 2004). 


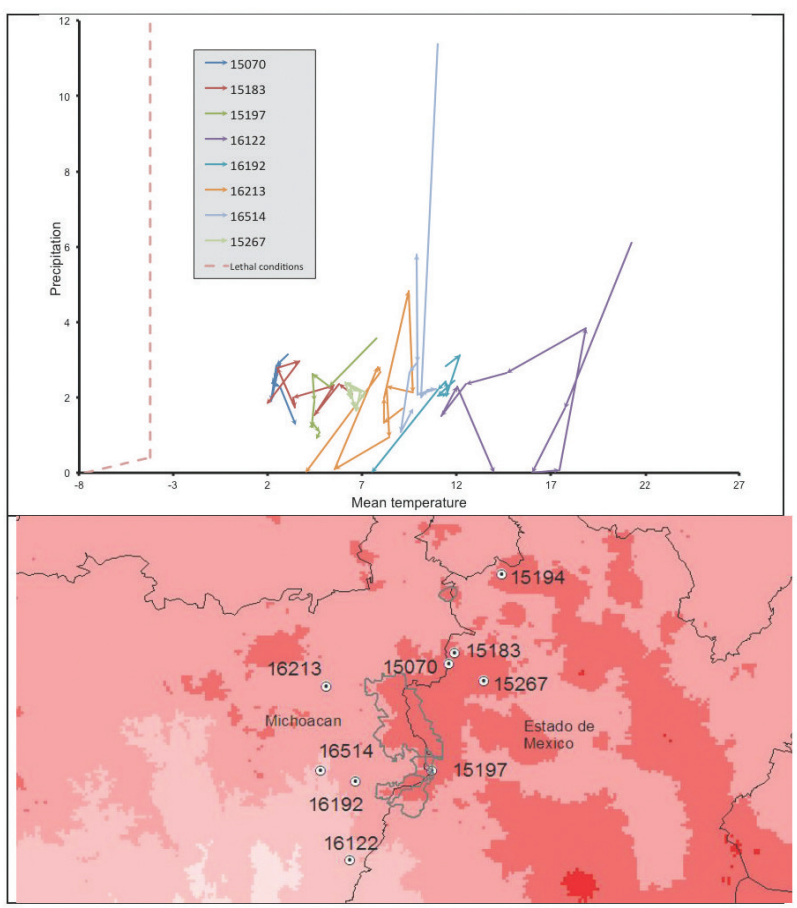

Figure 2. Illustration of trajectories through time for example weather stations within $25 \mathrm{~km}$ of monarch overwintering colonies (top), in terms of average distance to lethal climate conditions (dashed red line), 1995-present. Each vertex represents the average conditions over an entire winter season for one particular weather station. Map at bottom shows positions of the weather stations (dotted circles, numbers refer to Table 1) in relation to the limits of the Monarch Butterfly Biosphere Reserve (gray outline).

Recent winter mortality events (Brower et al., 2004) suggest such climate-change effects, and climate change effects on other butterflies have been demonstrated convincingly (Parmesan, 1996; Parmesan et al., 1999). Our results point to a regional climate change signal underlying overwintering monarch mortality. Climate conditions in Mexican overwintering areas are trending consistently toward conditions inimical to monarch survival (Oberhauser and Peterson, 2004): temperatures are trending downwards, closer to freezing conditions. Although precipitation exhibits mixed trends (Fig. 2), extreme events appear to be increasing in frequency, although our data were not sufficiently long-term to be able to document these changes.

One could argue that extreme events would be more informative than average conditions in these explorations (Katz and Brown, 1992). However, in light of the spatial and environmental separation between the weather stations and overwintering sites (Fig. 2, Table 1), we place greater trust in average conditions. Our 9 weather stations

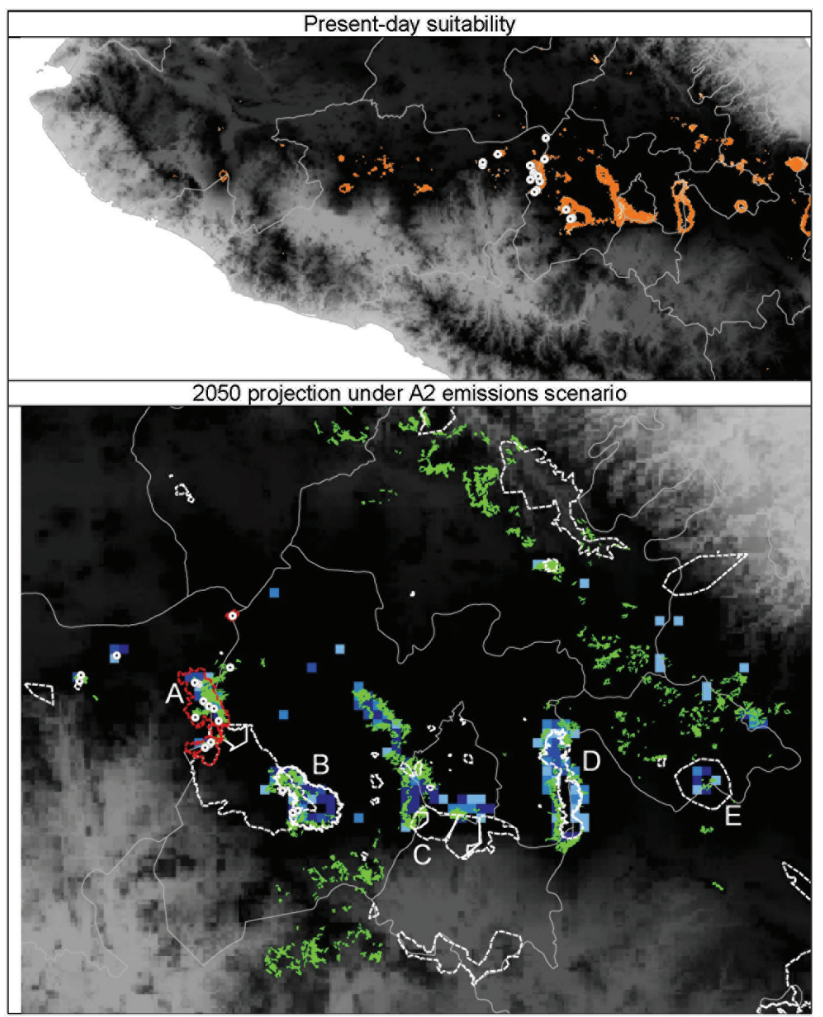

Figure 3. Present and future projections of suitability of climate conditions across central Mexico for overwintering monarch butterfly populations. The top panel shows a present-day suitability profile overlaid on elevation; present-day suitability is shown as an orange color ramp: lighter shades are less suitable, darker shades more suitable. In the bottom panel, projected future suitability is shown as a similar ramp in blue (HadCM3 A2 emissions scenario), overlaid on present-day distribution of native forest cover (in green; Mas et al., 2004). Occurrence data used to calibrate the models (and showing present-day positions of overwintering populations) are shown as dotted circles. Protected areas are shown as dashed white outlines; the current MBBR is shown as a dashed red outline; key areas are labeled with letters to permit discussion in the text.

are all located $\leq 25 \mathrm{~km}$ from overwintering sites, but none is in an overwintering colony area; most are at lower elevations than overwintering sites. Although higher sites generally experience lower temperatures (Dodson and Marks, 1997), the details of how precipitation acts in comparison to average conditions across surrounding landscapes are elusive. Initial explorations of correlations between temperatures at our weather stations and temperatures detected within overwintering sites over shorter time spans (Brower et al., 2009) showed no significant associations. Hence, given lack of long-term data on local weather within colony areas, extreme events at nearby weather stations will likely not represent true conditions there as well as averages. 


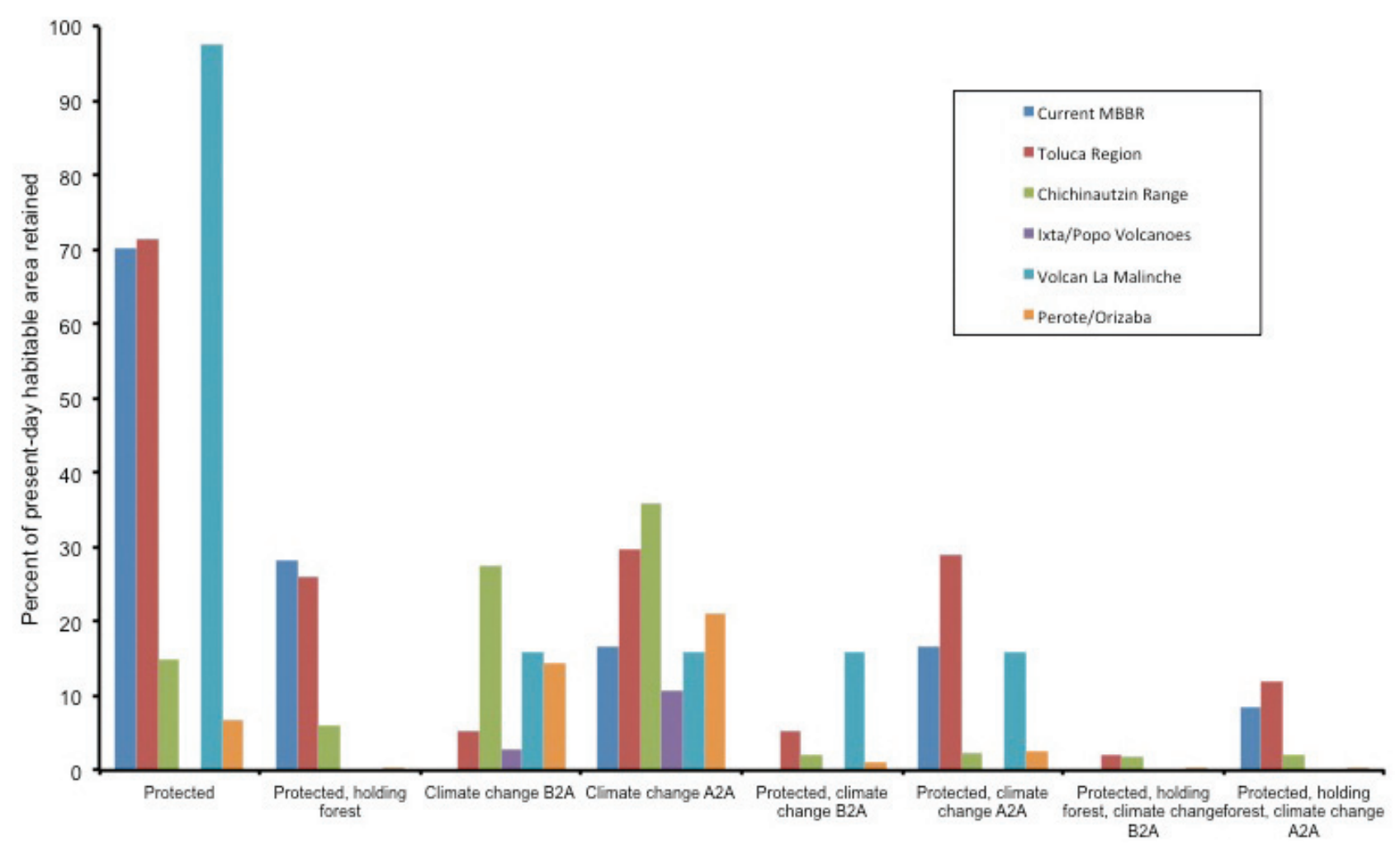

Figure 4. Summary of areal effects anticipated from future projections of ecological niche models for 6 regions of central Mexico that presently hold or could potentially hold overwintering populations of monarch butterflies.

\section{Discussion}

Analyses developed herein anticipate reduced viability of present-day overwintering sites in central Mexico, likely via extreme events that place overwintering populations under lethal conditions with increasing frequency. Relatively diffuse assemblages of overwintering monarchs have been known to exist elsewhere in Mexico for some time. That is, smaller and less densely aggregated monarch assemblages are found east of the present concentrations, in the mountains south and east of Mexico City (Calvert and Brower, 1986); although data are scarce, these aggregations may be increasing in numbers of individuals (R. de la Maza, pers. comm. with JS). These colonies may grow in the future with improving conditions, although the disjunct between habitable conditions, forested sites, and protected areas suggests that increases may be limited.

The mortality events that have been observed and documented recently are of significant dimension relative to the overall size of the Mexican overwintering populations (Brower et al., 2004), and possibly even of the North American populations of the species as a whole, given current declining trends in the western populations (Stevens and Frey, 2010) (D. Frey pers. comm.). If these trajectories continue, the possibility of significant reductions in central Mexican overwintering populations must be considered, and the phenomenon of ultraconcentrated overwintering populations in central Mexico could be reduced or eliminated.

The Monarch Butterfly Biosphere Reserve (MBBR) was established in 1980; another 1986 decree set official boundaries for the reserve (Brower et al., 2002), albeit without the benefit of detailed understanding of overwintering monarch ecology or of the social situation of the region's human communities. As a result, the 1986 decree met notable local resistance, including logging and burning of the Chivati-Huacal Mountain area within the MBBR (Honey-Rosés, 2009a), as well as scientific criticism (Missrie, 2004). A 2000 decree expanded the MBBR to unite the 5 previously-disconnected areas and include more known overwintering sites (Honey-Rosés, 2009a). Interviews with ejido (community) leaders at 2 monarch reserves in 2010 indicated that the local residents recognize the benefits of and need for government and NGO support in the region, but want more direct involvement in decision-making.

With the MBBR in place, logging activities within the reserve's core zones are prohibited, and only limited forest exploitation is allowed in buffer zones (Tucker, 2004; Brenner and Job, 2006). However, illegal logging 
continues, including for commercial purposes, in fact constituting the single greatest current cause of deforestation (Honey-Rosés, 2009a). Complicated interactions exist, involving both resistance and complicity, between illegal logging interests and disenfranchised members of some communities (Honey-Rosés, 2009b).

Some alternative income sources, largely related to tourism and scientific research initiatives funded by the Mexican government and NGOs, have appeared; however, equitable distribution of income within and among ejidos remains problematic. An important source of income is ecotourism, which was estimated to exceed US\$400,000 in 2006 (WCMC, 2007-2008); however, only 4 of nearly 60 ejidos in the area have been granted permission by Mexico's protected areas authority CONANP to establish tourism facilities, and much of income from tourism goes to hotel owners and tour-leaders not associated with communities. The Monarch Butterfly Conservation Fund provides Payment for Environmental Services (PES) to property owners who own land in the core zone and opt to participate in the fund (of the 38 eligible properties, 31 agreed to participate (WWF Mexico, 2000, 2002)). This participation rate is lower than other PES programs, probably reflecting local resistance and mistrust (HoneyRosés, 2009a; Honey-Rosés et al., 2009), and unwillingness to be held to the conservation criteria; indeed, illegal logging has occurred on variable scales within both the core and buffer zones since at least 1980. Payments are also provided for environmental services (e.g., reforestation) undertaken by communities lacking direct access to the monarch colonies. Other PES schemes could focus on carbon sequestration or payment for hydrological services, especially since the MBBR constitutes one of the main watersheds providing water to Mexico City.

If the monarch colonies that currently overwinter in the MBBR collapse, rarefy, or relocate, several political and social implications could ensue. If current restrictions on logging and mining remain in place, the income of communities relying on ecotourism could be in danger, and other sources of income would be unlikely to prove sufficient to support the entire region. The long-term commitment of the Mexican government and NGOs to the current area, were it to be without this spectacular biological phenomenon, is uncertain; they might rather channel funding only to areas with viable monarch colonies. If the monarch colonies relocate to other areas, whether these regions would also be protected by CONANP is unknown-very little of potential future monarch habitat is already under any Mexican federal protection (Fig. 4). If the new colonies are concentrated as in the MBBR, ecotourism initiatives could be developed on new overwintering grounds, providing new sources of income to these regions, but extensive investment in infrastructure for tourism in the present MBBR would be lost. In sum, reduction, collapse, or relocation of Mexican overwintering monarch colonies would result in economic hardship in the present MBBR, and would require difficult decisions by all stakeholders, with potentially serious social and financial implications for local communities and potentially serious ecological and conservation implications for the monarch migration phenomenon.

From a conservation perspective, the possibility that current wintering sites could become unsuitable for monarch overwintering does not mean that conservation actions at current sites should be de-emphasized. To the contrary, it is even more important to maintain a strong, viable present-day population that may be able to adapt to changing climatic conditions, and at a minimum can seed other populations that might establish. Monarch migratory behavior is remarkably plastic; indeed, human-mediated introductions of monarchs into Australia, New Zealand, and Hawaii have resulted in seasonal behaviors that are appropriate to very different climates. What the future actually holds for overwintering monarch populations in central Mexico, nonetheless, remains unclear.

\section{Acknowledgments}

We thank Rosendo Caro Gómez and Ernesto Enkerlin for insightful discussions; Lincoln Brower for extensive comments on earlier drafts of the manuscript; Andrés Lira-Noriega for technical assistance; Enrique Múñoz of the Comisión Nacional para el Conocimiento y Uso de la Biodiversidad for invaluable help with organizing and extracting meteorological data from the Servicio Meteorológico Nacional, and the ejidatarios of Rosario and Sierra Chincua for candid and helpful comments and reflections. Funding for IGERT activities was provided by NSF DGE-0801522; further funding was provided by Microsoft Research (grant to JS and ATP).

\section{Literature cited}

Alonso-Mejía, A., E. Rendón-Salinas, E. Montesinos-Patino and L. P. Brower. 1997. Use of lipid reserves by monarch butterflies overwintering in Mexico: implications for conservation. Ecological Applications 7:934-947.

Anderson, J. B. and L. P. Brower. 1996. Freeze-protection of overwintering monarch butterflies in Mexico: critical role of the forest as a blanket and an umbrella. Ecological Entomology 21:107-116.

Batalden, R. V., K. S. Oberhauser and A. T. Peterson. 2007. Ecological niches in sequential generations of eastern North American monarch butterflies: the ecology of migration 
and likely climate change implications Environmental Entomology 36:1365-1373.

Brenner, L. and H. Job. 2006. Actor-oriented management of protected areas and ecotourism in Mexico. Journal of Latin American Geography 5:7-27.

Brower, L. P. 1995. Understanding and misunderstanding the migration of the monarch butterfly (Nymphalidae) in North America: 1857-1995. Journal of the Lepidopterists' Society 49:304-385.

Brower, L. P., G. Castilleja, A. Peralta, J. López-García, L. Bojórquez-Tapia, S. Díaz, D. Melgarejo and M. Missrie. 2002. Quantitative changes in forest quality in a principal overwintering area of the monarch butterfly in Mexico, 19711999. Conservation Biology 16:346-359.

Brower, L. P., D. R. Kust, E. Rendón-Salinas, E. García-Serrano, K. R. Kust, J. Miller, C. Fernández del Rey and K. Pape. 2004. Catastrophic winter storm mortality of monarch butterflies in Mexico during January 2002. In Monarch Butterfly Biology and Conservation, K. Oberhauser and M. J. Solensky (eds.). Cornell University Press, Ithaca. p. 151-166.

Brower, L. P., E. H. Williams, D. A. Slayback, L. S. Fink, M. I. Ramírez, R. R. Zubieta, M. Ivan Limón García, P. Gier, J. A. Lear and T. Van Hook. 2009. Oyamel fir forest trunks provide thermal advantages for overwintering monarch butterflies in Mexico. Insect Conservation and Diversity 2:163-175.

Calvert, W. and L. P. Brower. 1986. The location of monarch butterfly (Danaus plexippus L.) overwintering colonies in Mexico in relation to topography and climate. Journal of the Lepidopterists' Society 40:164-187.

Calvert, W. H., W. Zuchowski and L. P. Brower. 1983. The effect of rain, snow and freezing temperatures on overwintering monarch butterflies in Mexico. Biotropica 15:42-47.

Dodson, R. and D. Marks. 1997. Daily air temperature interpolated at high spatial resolution over a large mountainous region. Climate Research 8:1-20.

García-Serrano, E., J. Lobato-Reyes and X. Mora-Álvarez. 2004. Locations and area occupied by monarch butterflies overwintering in Mexico from 1993-2002. In Monarch Butterfly Biology and Conservation, K. Oberhauser and M. J. Solensky (eds.). Cornell University Press, Ithaca. p. 129-134.

Gibo, D. L. and J. A. McCurdy. 1993. Lipid-accumulation by migrating monarch butterflies (Danaus plexippus L.). Canadian Journal of Zoology 71:76-82.

Hijmans, R. J., S. E. Cameron, J. L. Parra, P. G. Jones and A. Jarvis. 2005. Very high resolution interpolated climate surfaces for global land areas. International Journal of Climatology 25:1965-1978.

Honey-Rosés, J. 2009a. Disentangling the proximate factors of deforestation: The case of the Monarch Butterfly Biosphere Reserve in Mexico. Land Degradation \& Development 20:22-32.
Honey-Rosés, J. 2009b. Illegal logging in common property forests. Society and Natural Resources 22:916-930.

Honey-Rosés, J., J. Lopéz-García, E. Rendón-Salinas, A. PeraltaHiguera and C. Galindos-Leal. 2009. To pay or not to pay? Monitoring performance and enforcing conditionality when paying for forest conservation in Mexico. Environmental Conservation 36:120-128.

Katz, R. W. and B. G. Brown. 1992. Extreme events in a changing climate: variability is more important than averages. Climatic Change 21:289-302.

Larsen, K. J. and R. E. Lee. 1994. Cold tolerance including rapid cold-hardening and inoculative freezing of fall migrant monarch butterflies in Ohio. Journal of Insect Physiology 40:859-864.

Malcolm, S. B. and M. P. Zalucki, editors. 1993. Biology and Conservation of the Monarch Butterfly. Los Angeles Natural History Museum, Los Angeles, California. 419 p.

Missrie, M. 2004. Design and implementation of a new protected area for overwintering monarch butterflies in Mexico. Pages 141-150 In Monarch Butterfly Biology and Conservation, K. S. Oberhauser and M. J. Solensky (eds.). Cornell University Press, Ithaca. p. 141-150.

Oberhauser, K. S. and A. T. Peterson. 2004. Modeling current and future potential wintering distributions of eastern North American monarch butterflies. Proceedings of the National Academy of Sciences USA 100:14063-14068.

Parmesan, C. 1996. Climate and species' range. Nature 382:765766.

Parmesan, C., N. Ryrholm, C. Stefanescu, J. K. Hill, C. D. Thomas, H. Descimon, B. Huntley, L. Kaila, J. Kullberg, T. Tammaru, J. Tennent, J. A. Thomas and M. Warren. 1999. Poleward shift of butterfly species' ranges associated with regional warming. Nature 399:579-583.

Peterson, A. T., M. A. Ortega-Huerta, J. Bartley, V. SanchezCordero, J. Soberon, R. H. Buddemeier and D. R. B. Stockwell. 2002. Future projections for Mexican faunas under global climate change scenarios. Nature 416:626 - 629.

Peterson, A. T., J. Soberón, R. G. Pearson, R. P. Anderson, E. Martínez-Meyer, M. Nakamura and M. B. Araújo. 2011. Ecological Niches and Geographic Distributions. Princeton University Press, Princeton. 336 p.

Stevens, S. and D. Frey. 2010. Host plant pattern and variation in climate predict the location of natal grounds for migratory monarch butterflies in western North America. Journal of Insect Conservation 14:731-744.

Stockwell, D. R. B. and D. P. Peters. 1999. The GARP modelling system: Problems and solutions to automated spatial prediction. International Journal of Geographical Information Science 13:143-158.

Troyer, H. L., C. S. Burks and R. E. Lee. 1996. Phenology of cold hardiness in reproductive and migrant monarch butterflies (Danaus plexippus) in southwest Ohio. Journal of Insect 
Physiology 42:633-642.

Tucker, C. M. 2004. Community institutions and forest management in Mexico's Monarch Butterfly Reserve. Society and Natural Resources 17:569-587.

WCMC. 2007-2008. Mexico Butterfly; http://www.unepwcmc.org/sites/wh/pdf/Mexico\%20Butterfly.pdf; World Conservation Monitoring Centre, Cambridge; last access: 27.VIII.2010.
WWF Mexico. 2000. Convenios de Concertación WWF FMCNSEMARNAP - Comunidades; 24 Octuber 2000 Contractual Agreement. World Wildlife Fund Mexico, Mexico City.

WWF Mexico. 2002. Contrato de Fideicomiso Monarca WWFFMCN - BBVA Bancomer Servicios, S.A. Comunidades; Trust Contract. World Wildlife Fund Mexico, Mexico City. 